\title{
STUDENTS - BE ACTIVE! OUTLINES OF CHEMISTRY LESSONS AT SECONDARY SCHOOL ${ }^{1}$
}

\author{
Iwona Maciejowska' ${ }^{1}$ Ewa Odrovaž ${ }^{1,2}$ \\ ${ }^{I}$ Faculty of Chemistry, Jagiellonian University, Krakow, Poland, \\ ${ }^{2}$ Piarist Secondary School, Krakow, Poland
}

\begin{abstract}
Employers, career advisors and subsequently some education authorities emphasize the importance of the development of a wide range of transferable skills during school and university education. In order to develop these skills it is not enough just to expose students to a lecture or to a set of laboratory exercises in which they closely follow instructions provided by the teacher. It is necessary to implement problem solving or so-called "active methods" to achieve the aim. Some outlines of lessons that composed of different methods encouraging students to be active are presented.
\end{abstract}

Key words: problem solving, active method, outline, secondary school.

\section{Introduction}

"The deciding factor of successful teaching is the active participation of the learner." Polish Ministry of Education, On Pedagogical Supervision, 2000

Employers, career advisors (Fetzer, 2004) and subsequently some education authorities e.g. in Poland (Podstawa programowa, 2007) emphasize the importance of the development of a wide range of transferable skills during school and university education. Also associations of teachers point out to this issue, as testified by the final document of the last ICASE conference. (ICASE, 2003). Graduates should be able to use various sources of information (including multimedia), to work effectively in team, to present clearly results of their activity, to evaluate one's own work etc.

In order to develop these skills in our students it is not enough just to expose them to a lecture or to a set of laboratory exercises in which they closely follow instructions provided by the teacher. It is necessary to implement so-called "active methods" to achieve the aim (The Active Learning, on-line).

In active methods (Kędracka, 1999):

- the stress is moved from the teaching syllabus to the learner and the development of the learner's competencies;

- the learner is the active agent, who gains knowledge in the process of searching for the answers (applying trial-and-error method) and verifying own ideas;

- the teacher facilitates at process of learning by providing the learner with proper conditions to experiment, engaging the learner emotionally and encouraging him/her to think independently;

- the group dynamics processes are involved in-group work.

Active methods are especially useful in interdisciplinary teaching: science, environmental chemistry (Maciejowska, 2002, Sikosek \& Golob 2006).

\footnotetext{
${ }^{1}$ Manuscript is based on poster presentation: Maciejowska, I. \&. Odrowaz, E., Outlines of chemistry lessons at secondary school giving by active methods, $6^{\text {th }}$ ECRICE \& $2^{\text {nd }}$ ECCE 'A chemistry Odyssey', Programme and Abstracts, Aveiro 2001, p.307.
} 


\section{Outlines of chemistry lessons}

Below there are some outlines of lessons that composed of different methods encouraging students to be active. Usefulness of these methods was checked during chemistry lesson (Piarist Secondary School and V Liceum in Kraków) and summer-school organised for secondary school students: Gniezno 2000, Zakopane 2005 (Maciejowska, 2007).

\section{STAGING}

This technique is used to discuss various controversial issues, such as alcohols in human life. Stages:

- description of the working methods and sources of information;

- $\quad$ assignment of roles (judges, defenders, prosecutors, witnesses etc.);

- preparation of speeches and interrogations;

- the Sitting of the Court;

- conclusions

The final stage is of particular importance since the students usually have a great time during the classes, and yet the recapitulation of the most vital points of discussion and a summary are necessary.

The lesson has been carried out in $1^{\text {st }}$ year of the lower secondary school in Krakow (students age 15) on the topic 'Radioactivity'. There is a difficult topic to present, especially at this level of education. A judgment over radioactivity prepared by the pupils and focusing on the application of this phenomenon in real life and on its adverse impact brought positive results. The pupils were very-well prepared to play their roles, emotionally engaged and after the class admitted that they liked its form, whilst the information presented this way was acquired more easily. At the end of the lesson pupils found that radioactive elements are dangerous only in large doses, to which people are exposed only in non-typical situations.

Topic: The judgement over radioactivity $\left(1^{\text {st }}\right.$ year of secondary school $)$ - detailed description:

The operational purposes - pupil should:

- $\quad$ explain what do $\alpha$ and $\beta$ radioactive reactions rely on;

- define the properties of $\alpha$ and $\beta$ particles;

- give the features of nuclear radioactivity;

- point out the position of radioactive elements in the periodic table;

- mention negative effects of the radioactivity phenomenon;

- point out the examples of the uses of radioactive substances.

The lesson course:

A week before the planned date of "judgment", 2-3 judges are chosen from among the pupils. Their task is to introduce the topic, lead the discussion and to bring in a verdict. The remainders of the pupils are divided into two groups: prosecutors and defenders. From the literature advised by the teacher or other available sources of information, each group prepares issues: prosecutors - negative effects of radioactivity; defenders - use of radioactive substances. Pupils are also asked to prepare a proper disguise.

At the beginning of the lesson one of the judges mentions "the subject of the case" what is the nuclear radioactivity, which chemical elements are radioactive, what do $\alpha$ and $\beta$ radioactive reactions rely on. Next, the judges discuss: the prosecutors "accuse" the radioactivity of producing negative effects, and the defenders refute charges, giving the examples of application.

\section{METAPLAN}


Students should prepare a poster which is organised in special way (Brudnik, 2000):

The way it is

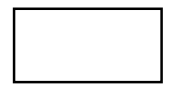

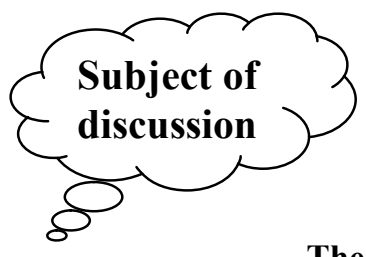

The way it should be
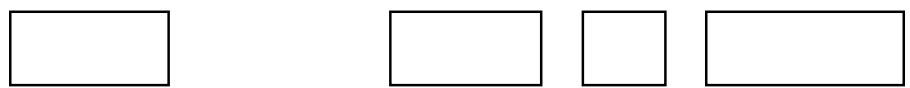

Why it is not the way it should be?

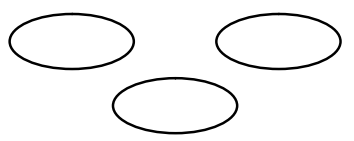

\section{Conclusions}

This technique is frequently applied to solve problems concerning environment protection, but also employed to optimize actions that need to be undertaken, or to deal with ethical issues.

Topic 'Air and its components' ( $1{ }^{\text {st }}$ year of lower secondary school $)$ - detailed description:

The operational purposes - pupil should:

- enumerate essential sources of air pollution;

- describe division of the pollution into the natural and industrial;

- mention the consequences the greenhouse effect;

- explain what is the ozone hole and what are the consequences of its occurrence.

The lesson course:

A week before the lesson the pupils are divided into groups of 5 persons. Each group gets one of the following topics: sources of air pollution; ozone hole; greenhouse effect. Pupils are getting ready for a given topic and also prepare short notes for their colleagues from other groups. During the lesson, the pupils present their topics on the A-0 size sheet of paper in the form of a poster. At the end of the lesson the poster can be presented and a note dictated for the colleagues. All the posters were hung out in the school chemical laboratory. The best poster was chosen in a competition taking into account a proper subject presentation and the performance aesthetics.

\section{Classical PROBLEM SOLVING METHOD}

At the class conducted with the use of the classical problem solving method the pupils were encouraged to formulate hypotheses on the basis of previously acquired knowledge and verify these hypotheses against the results of e.g. a chemical experiment (Davidson College, 2008). Below a part of the class on the reaction of oxides with water has been presented.

Topic: Do oxides react with water? $\left(2^{\text {nd }}\right.$ year of lower secondary school) - detailed description:

The operational purposes - pupil should:

- design an experiment which could help to state if metal oxides react with water; 
- mention basic oxides;

- write equations of the reactions of sodium, potassium, calcium and magnesium oxides with water.

The lesson course:

Recalling the knowledge about the non-metal oxide reaction with water, colours of indicators in acid and base solutions. Problem formulation: Do the metal oxides react with water? Having at disposal the following reagents: copper (II) oxide, calcium oxide, magnesium oxide, aluminium oxide, phosphorus (V) oxide, phenolphthalein, methyl orange, indicator paper, pupils in groups of 4-persons design an experiment which can help to solve the presented problem. Following the teacher acceptation of the project the pupils perform the experiment, write the observations, conclusions, equations of reactions and the generalization as an answer for the topic question.

\section{SNOWBALL (AVALANCHE)}

The discussion organized with the use of the snowball technique the pupils are asked to exchange their ideas with their colleagues sitting next to them. Then, the discussing groups are formed bigger and bigger according to the scheme:

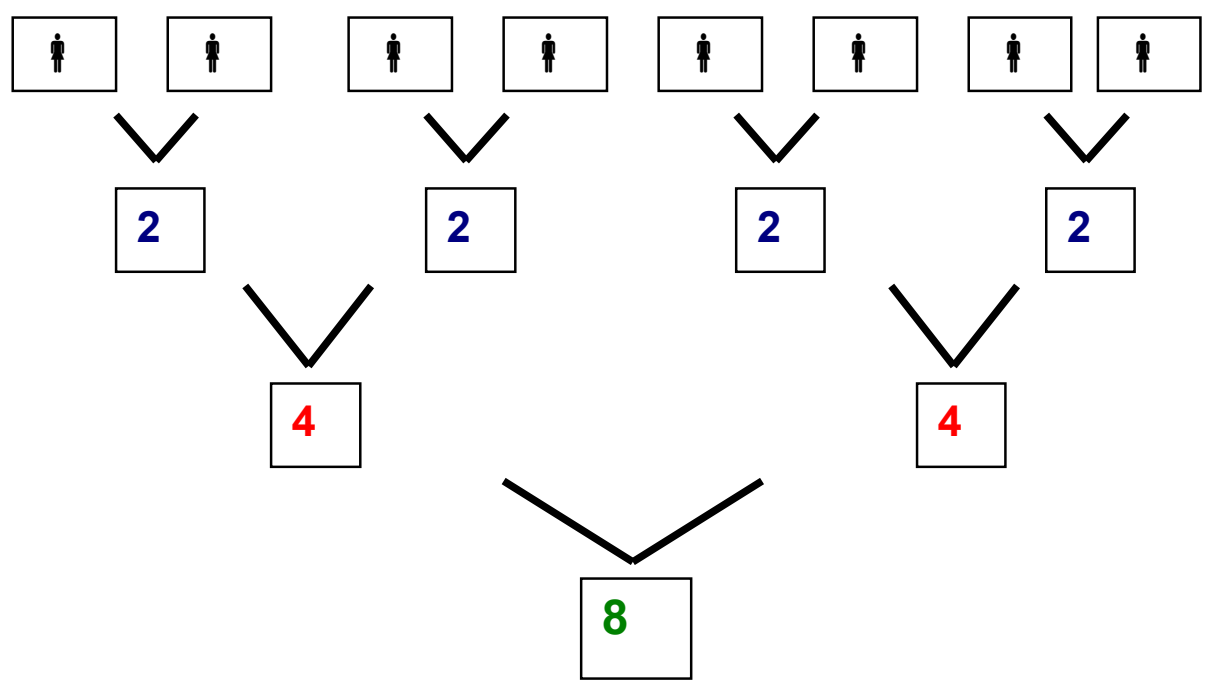

Such a lesson has been carried out as a lesson introductory to the section "Acids and bases". Out of many terms pupils selected those which they would associate with the word "acid". A discussion during choosing the terms was very vivid and enriching. Some reasons were very non-typical and thus interesting: e.g. sugar can be thought as a term opposed to that of the acid.

Topic: Acids in our environment $\left(2^{\text {nd }}\right.$ year of lower secondary school $)$ - detailed description The operational purposes - pupil should:

- give the names of acids known from everyday life with their division into those found in nature, used in household, medicine and in school chemical laboratory.

The lesson course: 
Each pupil gets a sheet of paper with a set of the following terms:

\begin{tabular}{|ll|}
\hline - sour taste & $\bullet$ nettle \\
- soap & $\bullet$ ant \\
- Coca-cola & $\bullet$ salicylic acid \\
- apple & $\bullet$ vitamin C \\
- wineral acids & $\bullet$ sater \\
- sugar & $\bullet$ vinegar \\
- car battery & $\bullet$ sunflower oil \\
- coal & $\bullet$ mineral oil \\
\hline
\end{tabular}

The pupil's task is to cancel one term, which is the least associated with acids. Then, the pupils consult their choice with their colleagues sitting next to them and then in the bigger groups. Lastly, a group of 5-pupils is to come to an agreement and to choose 5 terms, which, according to those pupils, are not associated with the term "acid". Each group choice can be written on the blackboard. In the next part of the lesson, the terms, which have not been chosen, are discussed and the chosen terms are verified, namely, if they really are not associated with acids. The last part of the lesson is dedicated to writing example acid names: acids known from everyday life; acids used in medicine; acids in school chemical laboratory.

Pupils liked this form of class, they could discuss and justify their associations and then jointly select the most appropriate ones, developing in this way, among others, oral communications skills.

\section{BRAINSTORMING}

(Delayed Evaluation Session, Exchange of Ideas, the Old Curiosity Shop of Ideas)

Although the brainstorming method has been used for years to solve the real problems in enterprises and also to teach business, it is not common in chemistry. The aim of these activities is to find out the largest number of unconventional solutions to presented problems. Even some of the once bizarre ideas were eventually put into practice: e.g. Jules Verne's Twenty Thousand Leagues under the Sea - the submarine; George Lucas film Star Wars the antimissile defence system. The specialists and laymen work together. An evaluation of ideas follows, which is done by another group of specialists. In the end the participants choose the best idea (through voting). The use of brainstorming holds promise as a pedagogical technique for developing students' skills in creative thinking and communication (Szlosek, 1999).

The structure of a Brainstorm - the classical form:

Stage 0 - choice of place and establishing time limits, choice of participants;

Stage 1 - introduction, defining the problem and aims;

Stage 2 - putting forward ideas, noting them down; ('green light' - each idea is accepted without any discussion)

\section{PART 2:}

Stage 3 - evaluation of the suggested ideas done in a new group of experts ('red light'), choice of the best solution or synthesis of the most interesting ideas;

Stage 4 - formulating the grounds of the choice, handing out the solution together with the justification to the customer. 
In order to adapt the above to school conditions, it is necessary to solve the following problems: Who will play the role of a layman and who of an expert? Who, and in what form, will evaluate the registered ideas? We may invite authentic experts or other chemistry teachers to the classes. It also seems worthwhile to broaden Stage 3 with a session during which students justify their proposals, and to introduce a plenary discussion on particular ideas. Stage 4 needs to include a summary of the lesson.

The problem of water pollution reduction was discussed with the youth attending the scientific camp (upper secondary school). They suggested some more standard solutions, such as the construction of small sewage treatment plants, or obtaining water from the river below the sewage release point but... they also proposed: to force the "flag of convenience" owners and petroleum producers to swim in the sea polluted with oil (Maciejowska, 2001).

Topic: Water pollution ( $1^{\text {st }}$ form of upper secondary school $)$ - detailed description

The operational purposes - pupil should:

- indicate sources of water pollution;

- enumerate ways of counteracting the contamination.

The lesson course:

- Introduction to the subject: kinds of pollution (solid, liquid, gaseous; organic and inorganic), sources (industry, city, agriculture etc.) consequences (diseases, corrosion and so on).

- Introduction to the form of work in a classroom - Brainstorming

- Defining the problem "How we can reduce water pollution?"

- $\quad$ Putting forward ideas, noting them down.

- Evaluation of the suggested ideas done in group of experts (authentic experts or other chemistry teachers, parents, older students) choice of the best solution or synthesis of the most interesting ideas (through voting).

\section{CASE STUDY}

The method objective is the analysis of a situation or event. A case study involves problem solving within a real life context. The use of case study provides an opportunity for helping students to acquire many of transferable skills (Bailey, 1997, Belt \& Overton, 2001) Since many of the best cases are based on the contemporary science problem that students encounter in the news, the use of cases in the classroom makes science relevant. Students exposed to the case method have been extraordinarily excited and actively involved in their learning.

The case study presented here uses the context of an environmental problem. The students were expected to suggest possible scenarios for a rescue operation. Also, the students need to take under consideration the economic aspects of their actions: e.g. the sources for obtaining the neutralising matter $-\mathrm{HNO}_{3}$, the costs of its obtaining, and the ways to utilize the resulting product. Their ideas are verified by finding out which method was actually adopted by the chemical rescue team. This case study was used in a lesson at the V Liceum in Kraków.

Topic: Reactions of neutralization ( $1^{\text {st }}$ year of upper secondary school) - detailed description. The operational purposes - pupil should:

- $\quad$ put down the equation of neutralisation reaction and define the composition of salt.

The lesson course:

1. Preliminary analysis of the problem - (presentation of the basic information, defining the problem, first suggestions). As an example a road accident resulting in a leak from a truck carrying $\mathrm{HNO}_{3}$ was given (report from an action of Chemical Rescue Team). 
2. Introduction of further details (enumerating limitations of certain solutions, searching for information).

3. Suggesting alternative solutions (exchange of information, solution proposals). Possible solutions: cover the leak with sand - absorption; neutralisation of the leak with ammonia or $\mathrm{NaOH}, \mathrm{Ca}(\mathrm{OH})_{2}, \mathrm{CaCO}_{3}$.

4. Reaching a decision (evaluation of advantages and disadvantages of suggested solutions).

5. Verification - comparison to the real action undertaken by rescue team.

\section{ROLE-PLAY METHOD}

Role-plays on social-environmental issues (Camino \& Calcagno, 1995) propose a multidisciplinary approach to real problems. The method consists in the preparation and staging of a role play. Participants are involved both at the cognitive and emotional level. As a result, the role play method is very effective. The method is used not only for solving environmental problems, but also purely chemical e.g. significance of sugars in the life of humans (Borowska, 2001)

Topic: Air pollution $\left(1^{\text {st }}\right.$ year of upper secondary school $)$ - detailed description

The operational purposes - pupil should:

- $\quad$ enumerate the basic kinds of air pollution;

- $\quad$ suggest methods of limiting air pollution;

- put down the equations of the reaction of carbon combustion;

- $\quad$ write down the formulae of sulphur oxide, carbon oxide and nitrogen oxide;

- indicate sources of water pollution and enumerate ways of counteracting the contamination.

The lesson course:

Teacher prepares role-play cards for the students. The roles suggested for that case: the mayor, an inspector at the Environment Protection Department of the Council Office, a chemistry teacher, a mother, a guide, a shopkeeper, a farmer, a doctor, a TPN (Polish Tatra National Park) employee, an unemployed person, etc.

Introduction to the subject

"You are the members of a Commune Council for the Tatra Mountains Region. The Region embraces both the urban complex of the Town of Zakopane, with its 30,000 inhabitants, and the picturesque Tatra Mountain Range with its unique flora and fauna (mountain pine, crocus, chamois, marmot) and unmatched topography. ... At the today's sitting of the council you need to decide whether you should give your consent to a proposition to build a hotel centre with such facilities as ski-lifts and swimming pools on the border of the city and "the National Park."

Supplement of students' knowledge - for their arguments the students may quote research data, but also the results of the experiments they have conducted themselves.

The activity allows for a discussion of such issues as: the renewable and nonrenewable energy sources, combustion processes, oxides production, air pollution, processes resulting in acid rains and the effect of the latter on various types of plants, mineral springs and the mineral salts they contain, the effect of $\mathrm{Pb}$ and $\mathrm{NO}_{\mathrm{x}}$ present in car fumes on human health, the mechanisms of smog, and many others.

\section{Summing-up}


The activities were aimed at solving real life problems. The learners discovered the underlying processes and rules. Students are completely active when intensive intellectual work, and when a variety of feelings and emotions is present support their visible activities such as motion or speech. In fact, each method of teaching may be adapted to become an activated method, if only we manage to make our students active using it. The easiest way to achieve the aim is to ask the question: Why? Why did I transform the formula in that way? Why is the process resulting in the following? (smoke, change of colour, clouding), etc.

\section{References}

Bailey, P. (1997). University Chemistry Education, 1, 31

Belt, S., Overton, T., Summerfield, S. (2001). $6^{\text {th }}$ ECRICE \& $2^{\text {nd }}$ ECCE 'A chemistry Odyssey', Programme and Abstracts, Aveiro, p. 177

Borowska, B. \& Panfil, V. (2001). Metody aktywizujace w edukacji biologicznej, chemicznej $i$ ekologicznej, Wydawnictwo TEKST, Bydgoszcz

Brudnik, E., Moszyńska, A. \& Owczarska, B. (2000). Ja i mój uczeń pracujemy aktywnie. Przewodnik po metodach aktywizujacych, Zakład Wydawniczy SFS, Kielce

Camino, E. \& Calcagno, C. (1995). An interactive methodology for 'empowering' students to deal with controversial environmental problems. Env. Educ. Res. 1 (1), p.59-74.

Davidson College, Department of Chemistry, A General Problem-Solving Strategy For Chemistry, http://www.chm.davidson.edu/ronutt/che115/Pro_Sol.pdf (01.06.2008)

Fetzer, J. (2004). Career Management for Chemists, Springer - Verlag, Berlin

ICASE, Increasing the Relevance of Science and Technology Education for All for the 21st Century, Penang 2003, http://www.icaseonline.net/ICASE2003WayForward.htm (01.06.2008)

Kędracka-Feldman, E. (1999). Wybrane metody i techniki aktywizacji uczniów, CODN, Warszawa

Maciejowska, I.(2001). „Nietoperz” Poradnik metodyczny dla nauczycieli i instruktorów. Edukacja ekologiczna, KKCh ZHP, Kraków

Maciejowska, I. (2002) Active learining/activating teaching - Suggested Approach for Interdisciplinary Education at Schools, Interdisciplinary education - challenge of $21^{\text {st }}$ century, red. I. Maciejowska, G. Stochel, Kraków . p.124-127

Maciejowska, I. (2007). Field trip as a way of working with a class with An extender chemistry and biology sylabus, Annals of the Polish Chemical Society, 2007, on-line http://www.pg.gda.pl/chem/InneJednostki/PTChem/Roczniki 2007/all annals.pdf

Podstawa programowa ksztatcenia ogólnego dla liceów ogólnoksztatcacych, MEN, http://bip.men.gov.pl/akty_prawne/rozporzadzenie_20070823_3.pdf (01.06.2008)

Sikosek, D. \& Golob, N. (2006) Problem-oriented interdisciplinary environmental education: what are the most effective approaches for chemistry teacher? , $8^{\text {th }}$ ECRICE, Budapest, Book of abstract p. 77

Szlosek, F. (1999). Dyskusja wielokrotna i burza mózgów, CODN, Warszawa

The Active Learning Site, http://www.active-learning-site.com/bib1.htm (01.06.2008)

Received 11 June 2008; accepted 10 August 2008

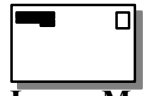

Iwona Maciejowska,

Faculty of Chemistry, Jagiellonian University

Ingardena 3, 30-525 Krakow, Poland

E-mail: maciejow@chemia.uj.edu.pl

Website: http://www.uj.edu.pl/index.en.html

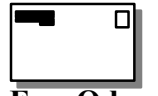

Ewa Odrowąz

Piarist Secondary School, Krakow, Poland

E-mail: odrowaz@chemia.uj.edu.pl 